\title{
Review
}

\section{Dissecting the Complexity of Early Heart Progenitor Cells}

\author{
Miquel Sendra ${ }^{1, *(\mathbb{D}}$, Jorge N. Domínguez ${ }^{2}\left(\mathbb{D}\right.$, Miguel Torres ${ }^{1}$ and Oscar H. Ocaña ${ }^{1, * \mathbb{C}}$ \\ 1 Developmental Biology Program, Centro Nacional de Investigaciones Cardiovasculares (CNIC), \\ 28029 Madrid, Spain; mtorres@cnic.es \\ 2 Cardiovascular Development Group, Department of Experimental Biology, University of Jaen, \\ 23071 Jaen, Spain; jorgendm@ujaen.es \\ * Correspondence: msendra@cnic.es (M.S.); ohocana@cnic.es (O.H.O.)
}

check for updates

Citation: Sendra, M.; Domínguez,

J.N.; Torres, M.; Ocaña, O.H.

Dissecting the Complexity of Early

Heart Progenitor Cells. J. Cardiovasc.

Dev. Dis. 2022, 9, 5. https://doi.org/

$10.3390 /$ jcdd 9010005

Academic Editors: Monique R.M.

Jongbloed and Robert Poelmann

Received: 1 December 2021

Accepted: 22 December 2021

Published: 26 December 2021

Publisher's Note: MDPI stays neutral with regard to jurisdictional claims in published maps and institutional affiliations.

Copyright: (c) 2021 by the authors. Licensee MDPI, Basel, Switzerland. This article is an open access article distributed under the terms and conditions of the Creative Commons Attribution (CC BY) license (https:// creativecommons.org/licenses/by/ $4.0 /)$.

\begin{abstract}
Early heart development depends on the coordinated participation of heterogeneous cell sources. As pioneer work from Adriana C. Gittenberger-de Groot demonstrated, characterizing these distinct cell sources helps us to understand congenital heart defects. Despite decades of research on the segregation of lineages that form the primitive heart tube, we are far from understanding its full complexity. Currently, single-cell approaches are providing an unprecedented level of detail on cellular heterogeneity, offering new opportunities to decipher its functional role. In this review, we will focus on three key aspects of early heart morphogenesis: First, the segregation of myocardial and endocardial lineages, which yields an early lineage diversification in cardiac development; second, the signaling cues driving differentiation in these progenitor cells; and third, the transcriptional heterogeneity of cardiomyocyte progenitors of the primitive heart tube. Finally, we discuss how single-cell transcriptomics and epigenomics, together with live imaging and functional analyses, will likely transform the way we delve into the complexity of cardiac development and its links with congenital defects.
\end{abstract}

Keywords: cardiac fields; cardiomyocyte; endocardium; progenitor specification; heart tube

\section{Introduction}

The heart is the first organ to form during embryogenesis. Following the onset of gastrulation, a primitive heart assembles and starts pumping nutrients to the whole embryo, while it continues developing. This remarkable ability to form and function simultaneously has attracted researchers for nearly a century, revealing that heart development involves the interplay between heterogeneous cell sources and complex morphogenetic processes [1]. With at least $0.8 \%$ of newborns presenting congenital heart defects [2], understanding heart development is of great interest. Adriana C. Gittenberger-de Groot and colleagues contributed extensively to this end, both characterizing the different cellular sources of the developing heart [3] and applying this knowledge to clinical goals [4].

A key step towards understanding organogenesis is finding how stem cells commit to different cell types. Studying the embryonic origin of the distinct cell populations contributing to an organ helps us to understand developmental defects by identifying within heterogeneous progenitor populations those contributing to specific cellular compartments and functions. In vertebrates, cardiac progenitors in the epiblast are among the earliest to ingress through the primitive streak and differentiate into mesoderm [5-8] (Figure 1). At this point, the transcription factor Mesp1 is transiently expressed, offering an accurate marker for nascent mesodermal cells including extrambryonic, cardiac and head/neck skeletal muscle progenitors [9]. Once they have migrated to the anterior pole, a subset of cardiac progenitors, known as the First Heart Field (FHF), starts expressing specific differentiation markers. By Early Head Fold (EHF) stage in mouse, embryonic day (E) $\sim 7.5$, the pre-myocardium is arranged as a columnar epithelium and the pre-endocardium lays between the pre-myocardium epithelium and the endoderm, revealing the first sign of cellular heterogeneity in the heart [10] (Figure 1, cellular detail of primitive heart tube 
progenitors) [11]. Subsequently, the pre-myocardial epithelium separates from the endoderm, creating bilateral hemi-tube structures with endocardial cells in its lumen. This primordium, known as the cardiac crescent in the mouse, undergoes morphogenesis fusing at the midline to form the primitive heart tube, which will contribute to the left ventricle and part of the atria in the mature heart. Continuous with the primitive heart tube, additional cardiac progenitors, known as the Second Heart Field (SHF), remain undifferentiated until recruited later to the right ventricle, outflow tract and the rest of the atria [12,13].
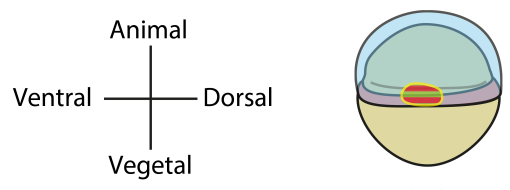

$40 \%$ epiboly $\sim 5 \mathrm{hpf}$

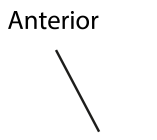

Posterior

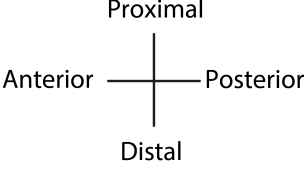

Epiblast / Ectoderm

Mesoderm

Endoderm

Primitive heart tube progenitors
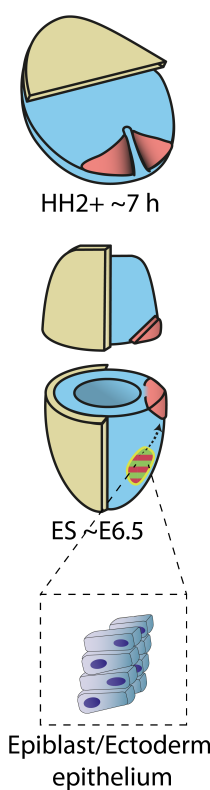

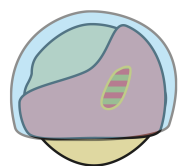

$70 \%$ epiboly $~ 8 \mathrm{hpf}$
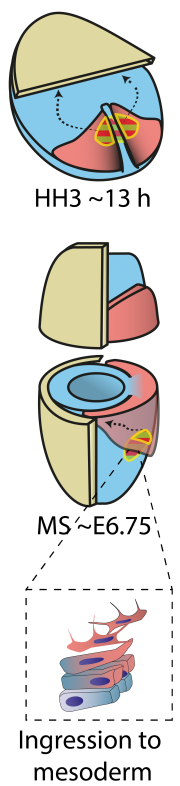

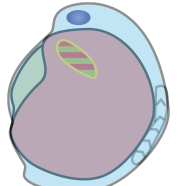

$6 \mathrm{~s} \sim 12 \mathrm{hpf}$
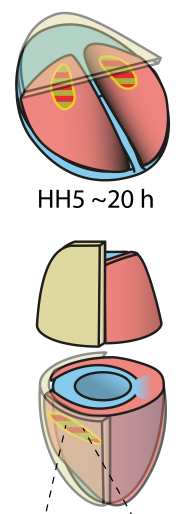

EHF E7.5

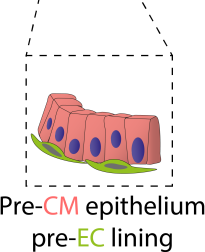

Zebrafish

Chicken

Mouse

Cellular detail of primitive heart tube progenitors

Figure 1. Location of cardiac progenitors in vertebrate models from the onset of gastrulation to the stage preceding primitive heart tube formation. Cardiac progenitors ingress the mesoderm soon after the start of gastrulation, migrating to the opposite side of the embryo to establish the two layers that form the primitive heart tube. The different rows of diagrams show this process in mouse, chicken, zebrafish and a zoom-in for the cellular detail of primitive heart tube progenitors, respectively. Zebrafish diagrams are depicted from dorsal views while those in chick and mouse show ventral views. Morphological staging follows the epiboly rate, Hamburger-Hamilton (HH) and Downs [14] criteria for zebrafish, chicken and mouse, respectively. Approximate time in hours post fertilization (hpf), hours (h) or embryonic day (E) are also provided. CM, cardiomyocytes; EC, endocardium. Dashed arrows depict the migration trajectory of primitive heart tube progenitors during gastrulation.

In this review, we dissect the earliest developmental events that contribute to generate the cellular heterogeneity and complexity of the heart. As other excellent publications review these aspects at later stages in both mammal [1,15,16] and zebrafish models [17], here we will focus on the formation of the primitive heart tube, using the mouse model as a reference. From classic labelling experiments (Table 1) to recent single-cell transcriptomic analysis $[18,19]$, we review studies that have expanded our views on cardiac heterogeneity and the mechanisms that generate it. Finally, we discuss the embryological relevance of such complexity, providing an overview of the public datasets that are available to study it further (Table 2). 
Table 1. Clonal analysis studies assessing early cardiac lineage segregation in vertebrate models.

\begin{tabular}{|c|c|c|c|c|c|c|c|c|c|}
\hline Model & Methodology & Stage & Location & $\mathbf{N}$ & & Prog & eny $(\%$ fro & m Total) & Reference \\
\hline & & & & & $\mathrm{CM}$ & EC & $\mathrm{CM}+\mathrm{EC}$ & $\begin{array}{c}\mathrm{CM}+\mathrm{EC}+ \\
\text { Non Cardiac }\end{array}$ & \\
\hline Zebrafish & $\begin{array}{l}\text { Single-cell dextran } \\
\text { microinjection }\end{array}$ & $\begin{array}{l}\text { Early blastula } \\
(\sim 2.75 \mathrm{hpf})\end{array}$ & $\begin{array}{l}\text { lateral-marginal } \\
\text { zone }\end{array}$ & 29 & 4 & 10 & 21 & 65 & [20] \\
\hline Zebrafish & $\begin{array}{l}\text { Single-cell dextran } \\
\text { microinjection }\end{array}$ & $\begin{array}{l}\text { Midblastula } \\
(\sim 3 \mathrm{hpf})\end{array}$ & $\begin{array}{l}\text { lateral-marginal } \\
\text { zone }\end{array}$ & 41 & 18 & 7 & 0 & 75 & [20] \\
\hline Zebrafish & $\begin{array}{c}2-3 \text { cells fluorescein } \\
\text { activation }\end{array}$ & $\begin{array}{l}40 \% \text { epiboly } \\
(\sim 5 \text { hpf })\end{array}$ & $\begin{array}{l}\text { ventral-marginal } \\
\text { zone }\end{array}$ & 69 & 44 & 52 & 4 & ND & [21] \\
\hline Zebrafish & $\begin{array}{c}\text { Kaede } \\
\text { photoconversion }\end{array}$ & $\begin{array}{l}\text { 14-somite } \\
(\sim 18 \mathrm{hpf})\end{array}$ & $\begin{array}{l}\text { anterior lateral } \\
\text { plate mesoderm }\end{array}$ & 39 & 27 & 0 & 2 & ND & [22] \\
\hline Chicken & $\begin{array}{l}\text { Replication-defective } \\
\text { retrovirus }\end{array}$ & $\begin{array}{c}\mathrm{HH} 3 \\
(\sim 14 \mathrm{~h}) \\
\end{array}$ & $\begin{array}{l}\text { anterior lateral } \\
\text { plate mesoderm }\end{array}$ & 82 & 95 & 5 & 0 & ND & [23] \\
\hline Chicken & $\begin{array}{l}\text { Replication-defective } \\
\text { retrovirus }\end{array}$ & $\begin{array}{l}\text { HH4 } \\
(\sim 18 \mathrm{~h})\end{array}$ & $\begin{array}{l}\text { rostral portion } \\
\text { primitive streak }\end{array}$ & 36 & $55^{*}$ & $45 *$ & 0 & ND & [23] \\
\hline Mouse & $\begin{array}{l}\text { Doxycyclin induced } \\
\text { transgene expression }\end{array}$ & $\begin{array}{l}\text { Early primitive } \\
\text { streak }(\sim \mathrm{E} 6.5)^{* *}\end{array}$ & $\begin{array}{l}\text { Mesp1-expressing } \\
\text { cells }\end{array}$ & 13 & 85 & 15 & 0 & ND & [24] \\
\hline Mouse & $\begin{array}{l}\text { Doxycyclin induced } \\
\text { transgene expression }\end{array}$ & $\begin{array}{l}\text { Late primitive } \\
\text { streak }(\sim \mathrm{E} 7.0)^{* *}\end{array}$ & $\begin{array}{c}\text { Mesp1-expressing } \\
\text { cells }\end{array}$ & 6 & 100 & 0 & 0 & ND & [24] \\
\hline Mouse & $\begin{array}{l}\text { Doxycyclin induced } \\
\text { transgene expression }\end{array}$ & $\begin{array}{l}\text { Late bud } \\
(\sim \mathrm{E} 7.5)^{* *}\end{array}$ & $\begin{array}{l}\text { Mesp1-expressing } \\
\text { cells }\end{array}$ & 17 & 70 & 6 & $24^{* * *}$ & ND & [24] \\
\hline
\end{tabular}

ND, Not Determined; hpf, hours post fertilization. * Including labeled clusters that consisted of both CM or EC but either tagged with cytoplasmic $\beta$-gal ( $\beta$-gal) or nuclear directed $\beta$-gal (n $\beta$-gal). ${ }^{* *}$ Estimated recombination stage. Mouse retrospective analyses can only offer an approximated stage as the precise mating time and litter variability are unknown. ${ }^{* * *}$ A third of the clusters also contain smooth muscle cells.

Table 2. Single-cell sequencing and live imaging data from mouse embryos available in the literature. Links to the raw and processed data and their website interfaces are provided when available (Data).

\begin{tabular}{|c|c|c|c|c|c|c|}
\hline Resource & Stage & Selection (N Cells) & Method & Depth * & Data & Reference \\
\hline scRNAseq & $\begin{array}{l}\mathrm{ES} \text { to } \mathrm{LHF} \\
\sim \mathrm{E} 6.5, \mathrm{E} 7.5, \mathrm{E} 7.75\end{array}$ & $\begin{array}{l}\sim \text { E6.5 epiblast }(501) \\
\sim \text { E7.5 Flk } 1^{+}(704)\end{array}$ & Smart-seq2 & $\begin{array}{l}\sim 1 \times 10^{6} \\
\text { reads } / \text { cell }\end{array}$ & link list 1 & [25] \\
\hline scRNAseq & $\sim \mathrm{E} 6.75, \mathrm{E} 7.25$ & $\begin{array}{l}\text { Mesp1 }^{+} \\
\left.\sim \text { E6.75 (83 WT } 85 \mathrm{Mesp} 1^{-/-}\right) \\
\sim \text { E7.25 (173) }\end{array}$ & Smart-seq2 & $\begin{array}{l}\sim 1 \times 10^{6} \\
\text { reads } / \text { cell }\end{array}$ & link list 2 & [26] \\
\hline scRNAseq & $\sim \mathrm{E} 8.25$ & Whole embryo $(19,396)$ & $\begin{array}{l}10 \times \\
\text { genomics }\end{array}$ & $\begin{array}{l}\sim 2 \times 10^{4} \\
\text { UMIs / cell }\end{array}$ & link list 3 & [27] \\
\hline scRNAseq & $\begin{array}{l}\text { ES to } 7 \mathrm{~s} \\
\sim \text { E6.5, E6.75, } \\
\text { E7.25, E7.5, E7.75, } \\
\text { E8.0, E8.25, E8.5 }\end{array}$ & $\begin{array}{l}\text { Whole embryo }(116,312) \\
\text { Per stage: supplementary }\end{array}$ & $\begin{array}{l}10 \times \\
\text { genomics }\end{array}$ & $\begin{array}{l}\sim 2 \times 10^{4} \\
\text { UMIs / cell }\end{array}$ & link list 4 & [28] \\
\hline scRNAseq & $\begin{array}{l}4 \mathrm{~s}, 8 \mathrm{~s}, 21 \mathrm{~s} \\
\sim \mathrm{E} 7.75, \mathrm{E} 8.25, \mathrm{E} 9.25\end{array}$ & $\begin{array}{l}\text { Dissected cardiac region } \\
\left.\text { E7.75 ( } 4326 \text { WT } 3535 \text { Hand2 }^{-/-}\right) \\
\left.\text {E8.25 (5664 WT } 4112 \text { Hand }^{-/-}\right) \\
\text {E9.25 (11,376 WT) }\end{array}$ & $\begin{array}{l}10 \times \\
\text { genomics }\end{array}$ & $\begin{array}{l}\sim 2 \times 10^{4} \\
\text { UMIs / cell }\end{array}$ & link list 5 & [29] \\
\hline
\end{tabular}


Table 2. Cont.

\begin{tabular}{|c|c|c|c|c|c|c|}
\hline Resource & Stage & Selection (N Cells) & Method & Depth * & Data & Reference \\
\hline scRNAseq & $\begin{array}{l}\text { LHF, } 8 \mathrm{~s}, 13 \mathrm{~s}, 20 \mathrm{~s} \\
\sim \text { E7.75, E8.25, } \\
\text { E8.75, E9.25 }\end{array}$ & $\begin{array}{l}\mathrm{Nkx2-5^{+ }}(690), \mathrm{Isl1}^{+}(640) \\
\text { Per stage: supplementary } 1\end{array}$ & $\begin{array}{l}\text { Modified } \\
\text { Smart-seq2 }\end{array}$ & $\begin{array}{l}\sim 1 \times 10^{6} \\
\text { reads/cell }\end{array}$ & link list 6 & [30] \\
\hline scRNAseq & $\begin{array}{l}\text { Pre-Streak stages } \\
\sim \text { E5.25, E5.5, } \\
\text { E6.25, E6.5 }\end{array}$ & $\begin{array}{l}\text { Whole embryo } \\
\text { E5.25 (331), E5.5 (269) } \\
\text { E6.25 (321), E6.5 (803) }\end{array}$ & Smart-seq2 & $\begin{array}{l}\sim 1 \times 10^{6} \\
\text { reads } / \text { cell ** }\end{array}$ & link list 7 & [31] \\
\hline scRNAseq & $\sim$ E7.5, E8.5, E9.5 & $\begin{array}{l}\text { Nkx2-5+ E7.5 (61), E8.5 (58) } \\
\text { E9.5 (81) } \\
\text { Is11 }{ }^{+} \text {E7.5 (30), E8.5 (167) } \\
\text { E9.5 (348 WT } 50 \text { Isl1 }^{-/-} \text {) }\end{array}$ & Smart-seq2 & $\begin{array}{l}\sim 1 \times 10^{6} \\
\text { reads/cell ** }\end{array}$ & link list 8 & [32] \\
\hline scRNAseq & $\begin{array}{l}\text { PrS to Presomitic } \\
\sim \text { E6.5 to E8.25 }\end{array}$ & $\begin{array}{l}\text { Whole embryo } \\
\text { (33,700 from } 153 \text { embryos) }\end{array}$ & MARS-seq & $\begin{array}{l}\sim 4 \times 10^{3} \\
\text { UMIs/cell }\end{array}$ & link list 9 & [33] \\
\hline scRNAseq & $\begin{array}{l}\text { LHF to } 4 \mathrm{~s} \\
\sim \mathrm{E} 7.75 \text { to } \mathrm{E} 8.25\end{array}$ & $\begin{array}{l}\text { dissected cardiac region } \\
(3105)\end{array}$ & Smart-seq2 & $\begin{array}{l}\sim 1 \times 10^{6} \\
\text { reads } / \text { cell ** }\end{array}$ & link list 10 & [18] \\
\hline scRNAseq & $\begin{array}{l}\text { 0B to somite stage } \\
\sim \text { E7.25 to E8.25 }\end{array}$ & $\begin{array}{l}\text { Mesp1+ }^{+} \\
(9072)\end{array}$ & $\begin{array}{l}10 \times \\
\text { genomics }\end{array}$ & $\begin{array}{l}60,450 \\
\text { UMIs/cell }\end{array}$ & link list 11 & [19] \\
\hline snATACseq & $\sim \mathrm{E} 8.5, \mathrm{E} 9.5$ & $\mathrm{Isl1}^{+}(695)$ & [34] & $\begin{array}{l}\sim 1.5 \times 10^{4} \\
\text { reads/nucleus* }\end{array}$ & link list 12 & [32] \\
\hline snATACseq & $\sim \mathrm{E} 8.25$ & Whole embryo $(19,453)$ & [35] & $\begin{array}{l}\sim 2 \times 10^{4} \\
\text { reads/nucleus * }\end{array}$ & link list 13 & [28] \\
\hline scNMTseq & $\begin{array}{l}\sim 4.5, \text { E5.5, } \\
\text { E6.5, E7.5 }\end{array}$ & Whole embryo (856) & {$[36]$} & $\begin{array}{l}\sim 1 \times 10^{6} \\
\text { reads/cell *** }\end{array}$ & link list 14 & [37] \\
\hline $\begin{array}{l}\text { Live } \\
\text { imaging }\end{array}$ & $\begin{array}{l}\mathrm{LB} \text { to } 4 \mathrm{~s} \\
\sim \mathrm{E} 7.5 \text { to } \mathrm{E} 8.5\end{array}$ & $\begin{array}{l}\text { Cardiac region: } 4 \text { embryos } \\
\text { Tdtomato mosaic } \\
\text { Nkx2-5:GFP }\end{array}$ & $\begin{array}{l}\text { Two-photon } \\
\text { microscopy }\end{array}$ & $\begin{array}{l}10 \mathrm{~min} \\
5 \mu \mathrm{m}\end{array}$ & NA & [13] \\
\hline $\begin{array}{l}\text { Live } \\
\text { imaging }\end{array}$ & $\begin{array}{l}\mathrm{LS} \text { to } 2 \mathrm{~s} \\
\sim \mathrm{E} 7.0 \text { to } \mathrm{E} 8.25\end{array}$ & $\begin{array}{l}4 \text { Whole embryos, } \\
\text { H2B:eGFP }\end{array}$ & $\begin{array}{l}\text { Adaptative } \\
\text { light-sheet } \\
\text { microscopy }\end{array}$ & $\begin{array}{l}4 \mathrm{~min} \\
2 \mu \mathrm{m}\end{array}$ & link list 15 & [38] \\
\hline $\begin{array}{l}\text { Live } \\
\text { imaging }\end{array}$ & $\begin{array}{l}\text { MS to LB } \\
\sim \mathrm{E} 6.75 \text { to } 7.5\end{array}$ & $\begin{array}{l}4 \text { Whole embryo: } \\
\text { T-cre } \\
\mathrm{mT} / \mathrm{mG} \text { mosaic }\end{array}$ & $\begin{array}{l}\text { Two-photon } \\
\text { microscopy }\end{array}$ & $\begin{array}{l}20 \mathrm{~min} \\
3 \mu \mathrm{m}\end{array}$ & NA & [39] \\
\hline
\end{tabular}

NA, not available; s, somite pairs. * Median reads or time-frame and $\mathrm{z}$ size are shown for scOmics or live imaging experiments, respectively. In scRNAseq, lower depth approaches amplify cDNA before sequencing to increase sensitivity. Before that, captured molecules are labeled with a unique molecular identifier (UMI). For more info read [40]. ${ }^{* *}$ Value not provided, calculated from the counts matrix. ${ }^{* * *}$ Corresponding to scRNAseq.

Link list (accessed on 25 December 2021):

1. Raw data https://www.ebi.ac.uk/arrayexpress/experiments/E-MTAB-4026/; Browser http:/ / gastrulation.stemcells.cam.ac.uk/scialdone2016

2. Raw data https://www.ncbi.nlm.nih.gov/geo/query/acc.cgi?acc=GSE100471; Browser http:/ / singlecell.stemcells.cam.ac.uk/mesp1

3. Raw and processed data https://www.ebi.ac.uk/arrayexpress/experiments/E-MTAB$6153 /$

4. Raw data https://www.ebi.ac.uk/arrayexpress/experiments/E-MTAB-6967/; Processed data https: / / github.com/MarioniLab /EmbryoTimecourse2018; Browser https:/ / marionilab.cruk.cam.ac.uk/MouseGastrulation2018/

5. Raw data https://www.ncbi.nlm.nih.gov/geo/query/acc.cgi?acc=GSE126128; Browser https: / / cells.ucsc.edu/?ds=mouse-cardiac

6. Raw data https://www.ncbi.nlm.nih.gov/geo/query / acc.cgi?acc=GSE109071

7. Raw data https://www.ncbi.nlm.nih.gov/geo/query/acc.cgi?acc=GSE108963

8. Raw and processed data https://www.ebi.ac.uk/ena/browser/view/PRJEB23303 ?show=reads

9. Raw and processed data https://www.ncbi.nlm.nih.gov/geo/query/acc.cgi?acc= GSE169210; Browser https: / / tanaylab.weizmann.ac.il/embflow /

10. Raw, processed data and Browser https://marionilab.cruk.cam.ac.uk/heartAtlas/; 
11. Raw data https://www.ncbi.nlm.nih.gov/geo/query/acc.cgi?acc=GSE176306; Browser https: / / cells.ucsc.edu/?ds=chi-10x-mouse-cardiomyocytes

12. Raw and processed data https://www.ebi.ac.uk/ena/browser/view/PRJEB23303 ?show=reads;

13. Raw and processed data https://www.ncbi.nlm.nih.gov/geo/query/acc.cgi?acc= GSE133244; Browser https:/ / gottgens-lab.stemcells.cam.ac.uk/snATACseq_E825/

14. Raw data https://www.ncbi.nlm.nih.gov/geo/query/acc.cgi?acc=GSE121708; Processed data ftp:/ / ftp.ebi.ac.uk/pub/databases/scnmt_gastrulation

15. Raw data https://idr.openmicroscopy.org/webclient/?show=project-502

\section{Cell Fate Specification Preceding Primitive Heart Tube Formation}

Once the primitive heart tube is assembled, it contains two cell types: cardiomyocytes (CMs), which form the muscular wall and endocardial cells (ECs), which are specialized endothelial cells lining the cardiac lumen [41]. Besides forming a continuum with the embryonic vasculature, ECs are involved in the formation of trabeculae [42-44] and contribute to the formation of the cardiac valves and septa $[45,46]$. ECs differ from other endothelial cells in their gene expression profile [47-49] and follow specific differentiation programs [42]. In the course of evolution, CMs arose from the transformation of mesenteric coelomic epithelium in early metazoans [50] while endothelial cells appeared later in vertebrates, likely from adherent hemocytes [51]. With these phylogenetic differences, CMs and ECs are found side-by-side at the anterior splanchnic mesoderm at the initiation of heart tube formation (Figure 1). Their ontogeny has been studied across multiple organisms, but it remains unclear if they originate from a homogeneous pool or from two distinct populations, pre-specified to adopt CM or EC fate $[11,52]$.

\subsection{Temporal Sequence of Fate Acquisition}

Knowing when a fate decision takes place is the first step to understand the mechanisms governing it. In classic embryology, a single cell or a group of cells is considered specified when it systematically yields a certain cell type. A tool to address the temporal sequence specification is clonal analysis [53]. By labelling single cells at different developmental stages and examining their progenies, one can infer when cell lineages become restricted-i.e., a progenitor cell that gave rise to both CMs and ECs was not specified to either fate at the time it was labelled. In prospective clonal analysis, researchers know the stage and location of the progenitor cell. This is achieved by direct labelling through manipulation of oviparous or ex utero viviparous embryos. In retrospective clonal analysis, cells are genetically labelled in utero so the embryonic stage and cell location are only approximated or unknown [54].

Clonal analysis experiments in zebrafish, chicken and mouse models traced the location of cardiovascular progenitors and pointed to an early specification of CMs and ECs, happening around the onset of gastrulation. To ease the interpretation of these valuable data, we summarized the experiments in Table 1. Prospective labelling in zebrafish early blastula (512 cells, $2.75 \mathrm{hpf}$ ) defined an area at the lateral marginal zone, enriched for unspecified cardiovascular progenitors [20]. Labelling the same area at $40 \%$ epiboly stage (5 hpf) yields few mixed progenies containing both CMs and ECs, indicating they are already specified when gastrulation begins [21]. Fate mapping in both cases shows that $\mathrm{CM}$ and EC progenitors are spatially intermingled. In chicken embryos, the rostral half of the primitive streak contains both cardiac progenitors $[55,56]$, which are already specified to form either CM or EC progenies [23,57]. Retrospective clonal analysis in mouse embryos also suggests an early specification. Genetically labelled Mesp1-expressing cells around the onset of gastrulation ( $\sim$ E6.25) give rise to clusters in the left ventricle at E14.5 containing either only CM or only EC [24]. Conversely, a quarter of Mesp1-expressing clones labelled at $\sim$ E7.25 gave rise to mixed progenies in the right ventricle [24], indicating that although the primitive heart tube arises from precursors that are already specified at gastrulation, later pools of progenitors from the second heart field can be multipotent [58]. In line with this re- 
sult, lineage tracing and in vitro studies have suggested the existence of mouse [58-62] and human [63] multipotent cardiac progenitors. A way to characterize further these progenitors would be to examine recent scRNAseq datasets for a cardiac multipotency signature in gastrulating mouse [18,28,29] and human embryos [64]. Together, these studies show CM and EC specification occurs at the onset of gastrulation or even before across vertebrate species, which is surprisingly long before the start of heart morphogenesis; however, pools of cardiac progenitors established later at the second heart field may remain multipotent.

Regardless of the timing of specification, the lineage relationship between CMs and ECs is controversial. Genetic lineage tracing of cardiac transcription factors and stem cell experiments support both cell types arise from a cardiac-specific common progenitor [11,59-61,65-67]. In contrast, zebrafish mid-blastula clones containing both CMs and ECs also give rise to blood vessels and blood cells [20] (Table 1), suggesting a CM-EC exclusive progenitor does not exist or it does very transiently. An alternative lineage tree proposes that ECs derive from the hematopoietic/vascular progenitors, and then migrate to populate the developing heart tube in zebrafish embryos [68,69]. To assess the lineage relationship among cardiac, hematoendothelial and other mesodermal progenitors, future clonal analysis experiments should examine the presence of labelled cells in all mesodermal tissues and not only in the heart [19]. New approaches such as CRISPR/Cas9based lineage tracing [70,71] and in toto live-cell tracking [38], will also help to answer this long-standing question.

\subsection{Molecular Mechanisms of Specification}

Understanding the mechanisms underlying cell fate decisions involves characterizing the cellular heterogeneity that precedes lineage specification [72]. A homogeneous niche of progenitors can segregate by various mechanisms to form subpopulations with different fates. Recently, the development of single cell transcriptomics and genomics transformed the way we study cellular heterogeneity in vivo $[28,37,73]$. The simultaneous characterization of the different cell populations forming an embryo allows one to make predictions about their ontogeny as well as showcasing gene regulatory networks responsible for it [74].

Single-cell RNA sequencing (scRNAseq) of gastrulating Mesp1-positive cells displays the transcriptional divergence of cardiac progenitors in vivo, revealing that CM and EC branches first diverge at $\sim$ E7.25 [26]. If pre-specified CM and EC progenitors exist at PS ingression ( $\sim$ E6.75 in mouse) — see Section 2.1—the transcriptional divergence captured at $\sim$ E7.25 by this approach may account for the earliest signs of differentiation but it remains unknown whether this segregation is a direct effect of their prior specification. Analyzing the trajectory of cardiac cells in emerging scRNAseq datasets (Table 2), especially in those prioritizing sequence depth over cell number, would shed light on whether transcriptional differences account for CM and EC early specification.

As demonstrated in Drosophila, single-cell chromatin accessibility mapping also allows identifying molecular processes involved in fate specification [75]. In addition to differences in RNA expression, epigenetic modifications contribute to cellular heterogeneity. As an example, early haematoendothelial clusters defined by scRNAseq in mouse can be further classified by their open chromatin regions corresponding to Tal1-bound cell-type specific enhancers [76]. Similarly, chromatin accessibility mapping in mouse E8.5 Isl1expressing cells reveals distinct epigenetic signatures, likely corresponding to differently fated progenitors [32]. This shows how cells within a scRNAseq cluster can differ in terms of accessibility to regulatory loci that account for changes in responsiveness to signaling cues. Thus, epigenetic analyses may distinguish fate specification in transcriptionally homogeneous populations, as these changes can anticipate RNA expression divergence. In fact, analysis of poised enhancers-distinguished from active enhancers by the H3K27me3 mark [77] - predicts developmental competence in human derived endodermal stem cells [78]. This, together with the functional relevance of chromatin remodeling complexes in gastrulation and cardiogenesis $[79,80]$ makes epigenetic heterogeneity a candidate mechanism 
to explain CM and EC early segregation in primitive heart tube formation. The increasing availability of single-cell transposase-accessible chromatin (scATACseq) methods [34] will likely motivate researchers to explore epigenetic heterogeneity in the coming years.

\section{Differentiation of Primitive Heart Tube Progenitors}

\subsection{Signaling Cues Driving CM and EC Differentiation}

After ingression, $\mathrm{CM}$ and EC progenitors migrate to the anterior-proximal side of the embryo proper (see Section 1 and Figure 1), where signaling cues from the subjacent endoderm promote their differentiation [81,82]. Integration of the BMP, FGF and Wnt pathways forges an environment that promotes primitive heart tube morphogenesis among vertebrate species [83]. For example, Bmp2 and $F g f 8$ zebrafish mutant embryos express less Nkx2-5 and differentiate fewer CMs. Removal of endoderm also causes a downregulation of cardiac markers in chicken, which can be rescued by supplying exogenous FGF8 or BMP2 [84]. In vitro, BMP2 released from anterior visceral endoderm cell lines induces CM generation in embryoid bodies [85]. On the other hand, Wnt $\beta$-catenin signaling prevents premature CM differentiation at the lateral plate mesoderm, but its expression is necessary for CM progenitor proliferation and ingression through the primitive streak [86]. In vitro, the timing of Wnt activation/deactivation cycles is also critical for CM differentiation in human induced pluripotent stem cells [87] and heart organoids [88]. Likewise, Wnt5amediated Wnt inhibition promotes EC differentiation in mouse early cardiac progenitors, while hindering CM differentiation [89]. Altogether, the signaling environment provided by the endoderm ensures that CM and EC differentiation occurs at the right time and location. In fact, the anterior intestinal portal can induce cardiac identity from non-cardiac mesoderm and pattern the ventricular and atrial domains in chicken, pinpointing the anterior endoderm as a heart organizer in vertebrates [90].

Besides diffusible cues, local signaling also plays a role in CM and EC differentiation. For example, cells with active Notch do not form CM colonies and forced activation of NOTCH1 in embryonic stem (ES) cells inhibits their differentiation to CM, while Notch inactivation promotes it $[91,92]$. This inhibitory effect also takes place in vivo: in Drosophila, loss and gain of function studies show Notch inhibits CM differentiation [93]; in Xenopus, Notch signaling limits the number of CM through the Serrate ligand [94]; in chicken, retroviral overexpression of Notch intracellular domain (NICD) in the heart tube reduces the expression of CM markers [95]; and in mouse, although NICD overexpression does not alter the number of CM or marker expression, it results in CM maturation defects including disrupted sarcomeric structures [96]. Conversely, Notch1 is required for the development of the endothelium $[97,98]$ and its expression marks mesodermal progenitors differentiating towards EC [26].

Unlike that of endothelial cells, CM differentiation is tightly coupled to gastrulation. Removal of the transcription factors Etv2 or Npas $4 l$ yields embryos that lack endothelial cells but undergo gastrulation normally, forming a heart tube without ECs $[99,100]$. To date, no genetic manipulation produced embryos that gastrulate but fail to form CMs: all mutants without CMs also fail to gastrulate, lacking all anterior mesoderm tissues [101-106]. In some of these, stuck mesodermal cells express CM differentiation markers [106] or even form bilateral heart tubes [9]. This suggests that once gastrulation is initiated successfully, CM differentiation will occur regardless of the anterior endoderm signaling cues [107]. In fact, gastrulation and early heart tube formation share many common genetic cascades implicating members of the Mesp transcription factor, Fgf and Wnt signaling pathways. An interpretation is that differentiation towards CM is determined concomitantly with gastrulation, or even represents the default state of anterior mesoderm, and the signaling environment may only modulate when and where the differentiation takes place. In support of this notion, non-cardiac mesoderm regions need to repress the CM programs to avoid ectopic differentiation $[69,108-110]$. 


\subsection{Redirection of Cardiac Progenitor Differentiation upon Perturbation}

Although primitive heart tube progenitors get specified to CMs and ECs at early stages (see Section 2.1), their definitive differentiation depends on surrounding signaling cues (see Section 3.1) and can be modified upon perturbation. In zebrafish, embryos lacking transcription factors as Tal1 and Etv2 have fewer ECs but expand their CM pool [42,108], with some Etv2 endothelial progenitors differentiating to CMs [108]. Indeed, scRNAseq shows FGF and Wnt signaling detours vascular progenitors towards a muscular fate in the absence of Etv2 [111]. In line with this, injecting Tal1 or Etv2 mRNA at the lateral plate mesoderm expands the endothelial domain while reducing the number of CMs [69]. In mouse, deletion of Tal1 yields CM-like differentiation in both yolk sac and endocardium through cell-autonomous Wnt antagonism [112]. Likewise, the enforced activation or inhibition of Wnt reduced or increased, respectively, endothelial differentiation in cardiac progenitors [89]. Finally, overexpression of Sox17, which is expressed downstream of Etv2, causes ectopic expression of PECAM1 endothelial marker in CMs [113].

Overall, these studies show CM and EC progenitors can modulate their fate in vivo upon perturbation of differentiation pathways, redirecting their fate even after specified. In vitro differentiation studies also illustrate the versatility of early mesodermal progenitors. A subset of ES-derived mesodermal cells, which start expressing Flk1, can differentiate to either CMs or ECs in a context-dependent manner [59,61]. Notably, a sub-population of the Flk1-negative ES-derived mesodermal cells can also be redirected in vitro towards a myocardial cell fate in mouse and human [114-116]. However, these results must be interpreted with caution, as stem cells can take differentiation roads that are not developmentally relevant.

\subsection{Plasticity of Cardiac Progenitors}

In early cardiac progenitors, cellular plasticity has been reported in vivo after primitive heart tube formation [1,117] and in ES cells models [118]. An example of in vivo cell plasticity is the interchangeability between atrial and ventricular CM progenitors. In chicken, cardiac ventricle progenitors derive from anterior regions of the cardiac mesoderm while atria progenitors arise from more posterior regions [55,119-122]. However, presumptive atrial cells can adopt ventricular properties when placed in the prospective ventricular domain [123] up to HH8 stage-when heart tube assembles. In mouse embryos, deletion of COUP-TFII in atrial CMs can switch their identity to ventricular CMs up to stage $\sim 12.5$, long after the formation of the cardiac chambers [124].

Together, the experiments cited in these three subsections show the definitive differentiation of cardiac progenitors is not fixed as it can change upon positional cues or intrinsic signaling perturbations. This way, despite the mechanisms normally involved in establishing the identity of cardiac cells, the signaling environment plays a role in their definitive differentiation [125].

\section{Molecular Heterogeneity of the Cardiomyocyte Sources within the Primitive Heart Tube}

Studying the molecular regulation of the different cell populations composing the primitive heart tube is important to understand their subsequent role in morphogenesis. Molecular signatures give us hints about cell behavior, features and susceptibility to signaling cues. Two recent outstanding papers have characterized the primitive heart tube transcriptional heterogeneity with unprecedented detail, reporting a novel cardiac progenitor pool that contributes to FHF cardiomyocytes and contains the earliest known progenitors of the epicardium $[18,19]$ (Figure 2). 
A

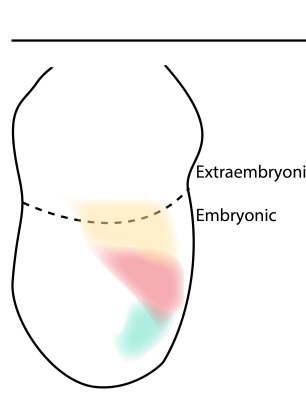

MS E6.75

B

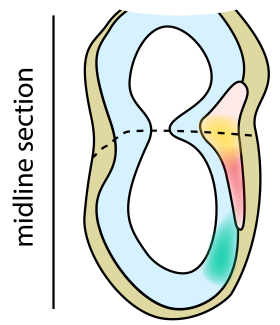

Sagittal view

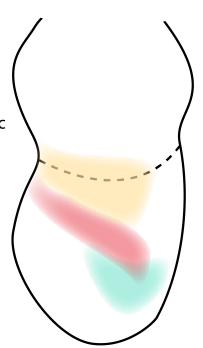

$\mathrm{OB} \sim \mathrm{E7} .25$

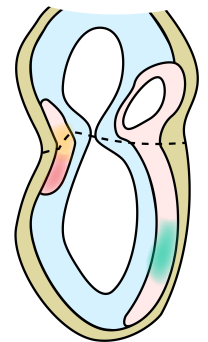

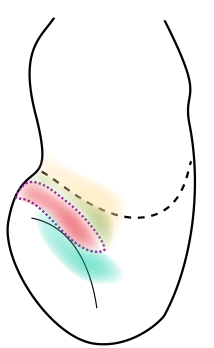

$\mathrm{LB} \sim \mathrm{E} 7.5$

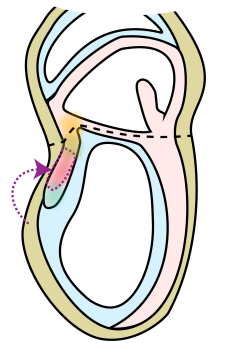

Frontal view

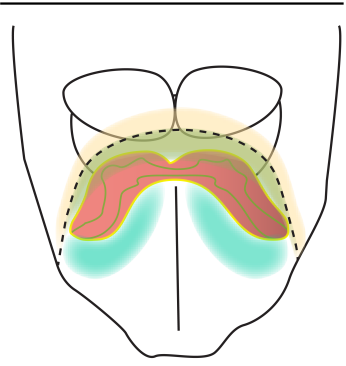

LHF E7.75

Figure 2. Progenitor domains contributing to heart tube cell populations in the mouse. Diagrams show whole embryos (A) and midline sections (B). Notice how the First Heart Field (FHF), Second Heart Field (SHF) and the recently characterized Mab21l2/Hand1 population stay in a continuum until differentiation cues recruit the FHF to form the primitive heart tube. In the section diagrams (B), endoderm, epiblast and mesoderm are painted in yellow, cyan and light red, following Figure 1 color code. Diagrams were done based on $[18,19]$.

Single-cell RNA sequencing (scRNAseq) of the mouse anterior cardiac region at cardiac crescent to linear heart tube stages ( $\sim$ E7.75 to $\sim$ E8.25) identified six different cardiac clusters in the anterior-proximal region of the embryo proper [18]. Differential expression analysis linked two of the clusters to the first and second heart field, respectively, while a third cluster represented an intermediate differentiation state between both. Strikingly, one of the clusters did not fit any previously known categorization, as it expressed some FHF markers, like Hand1 and Tbx5, but lacked canonical differentiation markers, such as $N k \times 2-5$. RNA fluoresence in situ hybridization of marker Mab21l2, a protein coding gene implicated in cardiac and neural development [126,127], mapped this novel cluster at the rostral border of the cardiac crescent, forming a narrow band of splanchnic mesoderm at the confluence of the embryonic and extraembryonic compartments of the embryo (Figure 2).

Analysis of the scRNAseq data revealed two distinct trajectories towards differentiated CMs, parting from the SHF cluster and the Mab21l2 cluster, respectively; the first connected SHF to differentiated CM via an intermediate state, which likely corresponds to the incorporation of SHF progenitors to the heart tube at the arterial pole $[13,128,129]$; the second trajectory linked the newly identified Mab21l2 cluster to differentiated CM via another intermediate state, unveiling a previously undescribed source of CMs. Lineage tracing of cells expressing Mab21l2 at $\sim$ E6.5-E7.5 yielded left ventricle CMs as well as epicardial cells. However, this cluster does not contribute to CMs of the right ventricle or outflow track. This implies that the Mab21l2 cluster, dubbed Juxta Cardiac Field (JCF) by the authors, supplies CMs to the FHF and contains the earliest known progenitors of the epicardium.

With a similar strategy, scRNAseq and trajectory analysis of Mesp1-expressing cells from $\sim$ E7.25-E8.25 mouse embryos also predicted a cardiac population [19] that partially overlaps the Mab21l2 cluster [18] but expands beyond the extraembryonic boundary (Figure 2). Lineage tracing of Hand1-expressing cells at $\sim$ E5.75-E6.75 yielded a contribution to the heart tube similar to that of the Mab2112 cluster [18], reinforcing the idea of the cardiac potential this cell population. In addition, retrospective clonal analysis of Hand1-expressing 
cells at $\sim$ E6.75-E8.25 revealed that these progenitors are multipotent. While most progenies contributed only to the yolk sac, a fourth contained a mixture of two or three distinct lineages including yolk sack, pericardium, proepicardium and atrioventricular canal or left ventricle CM [19]. As retrospective analyses render only approximate staging, multipotent clones may have resulted either from early inductions at the primitive streak or from later mesodermal cells that cross the embryonic/extraembryonic boundary. The latter would disagree with live imaging data reporting a clear segregation between embryonic and extraembryonic cells following the onset of gastrulation [39]. Estimating the induction time of the clones from their cell counts or prospectively labelling the Hand1 domain would clarify for how long this novel population remains multipotent.

Altogether, these studies uncover a previously uncharacterized cardiac progenitor population contributing mainly to the left ventricle and epicardium. In both publications, this population lies at the embryonic/extraembryonic boundary and constitutes a spatially and transcriptionally distinct population from Tbx18-expressing sinus venosus progenitors, which are recruited from a more caudal splanchnic mesoderm area [130]. While the first study defined this population at cardiac crescent stages $(\sim$ E7.75) using Mab2l12 as a marker [18], the second described a broader and earlier population expressing Hand1 at E6.25-E7.25 [19], making the Mab21l2 domain a likely subset among Hand1-expressing cells (Figure 2). Whether this population remains multipotent at cardiac crescent stages or only holds this ability at earlier stages is a pending question.

\section{Discussion and Future Perspectives}

Early heart development is a complex process involving heterogeneous sources of cell progenitors. Such complexity allows the heart to function while it keeps forming but makes the process susceptible to errors, likely responsible for the high incidence of congenital heart defects. Although single-gene mutations are linked to certain rare diseases [131], understanding the wide spectrum of congenital heart defects requires the integration of multiple gene regulatory networks that pattern the heterogeneous set of cellular functions in the heart.

An early lineage diversification in cardiac development emerges around gastrulation, when progenitor cells specify towards myocardial and endocardial fates. Chicken and zebrafish prospective clonal analysis demonstrate CM and EC progenitors are already segregated once they are recruited to the mesoderm, with retrospective experiments in mouse suggesting a similar outcome (see Section 2.1). However, it is still unclear when this fate decision takes place and what are the mechanisms governing it. Classic precepts consider that a common cardiac progenitor bifurcates into either CM or EC, but alternative models suggest ECs derive from a common endothelial lineage, shared with the rest of the vessels in the embryo proper and yolk sac (see Section 2.1). As the endothelium is a relatively recent innovation in evolution, this raises the question of whether early vertebrates recycled the CM program in the mesoderm to form endothelial cells and build complex circulatory systems. A dedicated analysis of single-cell genomics and live imaging data (Table 2) will likely define the ontogeny of CM and EC populations, charting the definitive Waddington landscape [132] of primitive heart tube specification. Interpretation of the big data generated by these approaches requires the use of programming and mathematics [133], but step-by-step tutorials allow researchers from a life sciences background to access these tools [40]. In fact, an increasing number of papers are setting an example by providing user-friendly guidance on the use of their code, easing the reanalysis of their data [28,38].

In a broader view, these high-resolution data are reshaping our perspectives on how embryos develop. In classic embryology textbooks, embryos were classified into two broad categories: regulative and mosaic embryos [134]. In the first type, characteristic of vertebrates, cells organize to form different organs by regulating their fate "on the go" through interactions with their surroundings. Regulative embryos can adapt to perturbations as cell decisions are continuously rechecked according to positional information and the signaling environment. In mosaic embryos, characteristic of the invertebrates, each cell or group 
of cells have a restricted fate, which is acquired autonomously through intrinsic factors. A century later, we know that in reality all embryos are both mosaic and regulative to some extent. Ascidian and nematode embryos, examples of stereotyped development with invariant cell lineages, also employ cell-cell contacts and cytokine signaling to orchestrate organ differentiation once they reach a certain cell number $[135,136]$. Conversely, mouse ES cells cannot contribute to some extraembryonic tissues such as the trophoblast and primitive endoderm, suggesting an intrinsic restriction in cell potency in early vertebrate embryos [137]. Thus, as shown in this review for the primitive heart tube, both intrinsic cell heterogeneity and signaling cues collaborate to progressively define cellular identity during embryo development.

In the discussion between regulative and predetermined conceptions, the division of cardiac progenitors as multiple predefined populations is a topic of debate. While some studies show an early segregation of the first and second heart field as predetermined populations with distinct susceptibility to differentiation $[24,26,58]$, others argue that the earlier differentiation of the FHF is governed by positional cues and not by intrinsic cellular differences [138]. Likewise, the recently characterized Mab2112/Hand1 progenitors contributing to cardiomyocytes and epicardium (see Section 4 and Figure 2) could be defined as a separate cardiac field. In favor of this notion, these progenitors show a unique transcriptomic signature and contribute systematically to specific regions of the heart. Nonetheless, it still remains to be tested whether the contributions of these regions are essential for heart development. In the case of FHF and SHF, elimination of the contribution of either population results in fatal cardiac malformations [139], whereas elimination of the contribution of these newly described regions to the cardiomyocyte pool has not been explored. On the other hand, the definition of developmental fields based solely on the recombination pattern of a particular transgene poses some questions, like whether the transgene labels cells before the full specification of the fields. In any case, the description of these novel Mab2112/Hand1 progenitors deepens our understanding on the heterogeneous sources of the cells that form the heart tube. A key question that arises is whether these heterogeneous sources confer developmental robustness and functional diversity to the mammalian heart. In that sense, it will be interesting to assess whether the Mab21l2/Hand1 progenitors are also present in anamniotes [17] or instead constitutes an evolutionary novelty that contributed to increase the complexity of the heart tube. Thus, exploiting single-cell omics and live-imaging data will lead to novel insights in understanding heart development (Table 2). The same way pioneer work by Gittenbergerde Groot and colleagues illuminated the different sources contributing to the arterial pole [140], identifying the states of the interacting components of the heart will continue to shed light on our understanding of congenital heart defects.

Author Contributions: Writing-original draft preparation, M.S., O.H.O.; writing-review and editing, M.S. O.H.O. J.N.D., M.T. All authors have read and agreed to the published version of the manuscript.

Funding: Stated in acknowledgements.

Institutional Review Board Statement: Not applicable.

Informed Consent Statement: Not applicable.

Data Availability Statement: Not applicable.

Acknowledgments: Grant support PGC2018-096486-B-I00 from the Spanish Ministerio de Ciencia eInnovación and Grant H2020-MSCA-ITN-2016-722427 from the EU Horizon 2020 program to MT.MS was supported by a La Caixa Foudation PhD fellowship (LCF/BQ/DE18/11670014) and TheCompany of Biologists travelling fellowship (DEVTF181145). OH.O. is supported by the Ministerio deCiencia e Innovación (grant RTI2018-097617-J-I00). The CNIC is supported by the Spanish Ministeryof Science and the ProCNIC Foundation.

Conflicts of Interest: The authors declare no conflict of interest. 


\section{References}

1. Meilhac, S.M.; Buckingham, M.E. The deployment of cell lineages that form the mammalian heart. Nat. Rev. Cardiol. 2018, 15, 705-724. [CrossRef]

2. Zimmerman, M.S.; Smith, A.G.C.; Sable, C.A.; Echko, M.M.; Wilner, L.B.; Olsen, H.E.; Atalay, H.T.; Awasthi, A.; Bhutta, Z.A.; Boucher, J.L.A.; et al. Global, regional, and national burden of congenital heart disease, 1990-2017: A systematic analysis for the Global Burden of Disease Study 2017. Lancet Child Adolesc. Health 2020, 4, 185-200. [CrossRef]

3. Gittenberger-de Groot, A.C.; Winter, E.M.; Bartelings, M.M.; Jose Goumans, M.; DeRuiter, M.C.; Poelmann, R.E. The arterial and cardiac epicardium in development, disease and repair. Differentiation 2012, 84, 41-53. [CrossRef] [PubMed]

4. Gittenberger-De Groot, A.C.; Moulaert, A.J.; Harinck, E.; Becker, A.E. Histopathology of the ductus arteriosus after prostaglandin E1 administration in ductus dependent cardiac anomalies. Br. Heart J. 1978, 40, 215-220. [CrossRef]

5. Lawson, K.A.; Pedersen, R.A. Clonal analysis of cell fate during gastrulation and early neurulation in the mouse. Ciba Foundation Symp. 1992, 165, 3-21. [CrossRef]

6. Lawson, K.A.; Meneses, J.J.; Pedersen, R.A. Clonal analysis of epiblast fate during germ layer formation in the mouse embryo. Development 1991, 113, 891-911. [CrossRef] [PubMed]

7. Tam, P.P.; Zhou, S.X. The allocation of epiblast cells to ectodermal and germ-line lineages is influenced by the position of the cells in the gastrulating mouse embryo. Dev. Biol. 1996, 178, 124-132. [CrossRef] [PubMed]

8. Tam, P.P.; Behringer, R.R. Mouse gastrulation: The formation of a mammalian body plan. Mech. Dev. 1997, 68, 3-25. [CrossRef]

9. Saga, Y.; Miyagawa-Tomita, S.; Takagi, A.; Kitajima, S.; Miyazaki, J.I.; Inoue, T. MesP1 is expressed in the heart precursor cells and required for the formation of a single heart tube. Development 1999, 126, 3437-3447. [CrossRef] [PubMed]

10. Street, D. Early differentiation of the heart in mouse embryos. J. Anat. 1981, 133, 235-246.

11. Harris, I.S.; Black, B.L. Development of the endocardium. Pediatr. Cardiol. 2010, 31, 391-399. [CrossRef] [PubMed]

12. Buckingham, M.; Meilhac, S.; Zaffran, S. Building the mammalian heart from two sources of myocardial cells. Nat. Rev. Genet. 2005, 6, 826-835. [CrossRef]

13. Ivanovitch, K.; Temiño, S.; Torres, M. Live imaging of heart tube development in mouse reveals alternating phases of cardiac differentiation and morphogenesis. eLife 2017, 6, e30668. [CrossRef] [PubMed]

14. Downs, K.M.; Davies, T. Staging of gastrulating mouse embryos by morphological landmarks in the dissecting microscope Development (Camb. Engl.) 1993, 118, 1255-1266. [CrossRef]

15. Jensen, B.; Christoffels, V.M.; Moorman, A.F. An appreciation of anatomy in the molecular world. J. Cardiovasc. Dev. Dis. 2020, 7, 44. [CrossRef]

16. Kelly, R.G.; Buckingham, M.E.; Moorman, A.F. Heart fields and cardiac morphogenesis. Cold Spring Harb. Perspect. Med. 2014, 4, a015750. [CrossRef]

17. Kemmler, C.L.; Riemslagh, F.W.; Moran, H.R.; Mosimann, C. From stripes to a beating heart: Early cardiac development in zebrafish. J. Cardiovasc. Dev. Dis. 2021, 8, 1-21. [CrossRef] [PubMed]

18. Tyser, R.C.; Ibarra-Soria, X.; McDole, K.; Jayaram, S.A.; Godwin, J.; Brand, T.A.D.; Miranda, A.M.; Scialdone, A.; Keller, P.J.; Marioni, J.C.; et al. Characterization of a common progenitor pool of the epicardium and myocardium. Science 2021, 371, eabb2986. [CrossRef]

19. Zhang, Q.; Carlin, D.; Zhu, F.; Cattaneo, P.; Ideker, T.; Evans, S.M.; Bloomekatz, J.; Chi, N.C. Unveiling Complexity and Multipotentiality of Early Heart Fields. Circ. Res. 2021, 129, 474-487. [CrossRef] [PubMed]

20. Lee, R.K.; Stainier, D.Y.; Weinstein, B.M.; Fishman, M.C. Cardiovascular development in the zebrafish II. Endocardial progenitors are sequestered within the heart field. Development 1994, 120, 3361-3366. [CrossRef]

21. Keegan, B.R. Organization of cardiac chamber progenitors in the zebrafish blastula. Development 2004, 131, 3081-3091. [CrossRef]

22. Mao, L.M.; Boyle Anderson, E.A.; Ho, R.K. Anterior lateral plate mesoderm gives rise to multiple tissues and requires tbx5a function in left-right asymmetry, migration dynamics, and cell specification of late-addition cardiac cells. Dev. Biol. 2021, 472, 52-66. [CrossRef] [PubMed]

23. Wei, Y.; Mikawa, T. Fate diversity of primitive streak cells during heart field formation in ovo. Dev. Dyn. 2000, 219, 505-513. [CrossRef]

24. Lescroart, F.; Chabab, S.; Lin, X.; Rulands, S.; Paulissen, C.; Rodolosse, A.; Auer, H.; Achouri, Y.; Dubois, C.; Bondue, A.; et al. Early lineage restriction in temporally distinct populations of Mesp1 progenitors during mammalian heart development. Nat. Cell Biol. 2014, 16, 829-840. [CrossRef]

25. Scialdone, A.; Tanaka, Y.; Jawaid, W.; Moignard, V.; Wilson, N.K.; Macaulay, I.C.; Marioni, J.C.; Göttgens, B. Resolving early mesoderm diversification through single-cell expression profiling. Nature 2016, 535, 289-293. [CrossRef]

26. Lescroart, F.; Wang, X.; Lin, X.; Swedlund, B.; Gargouri, S.; Sànchez-dànes, A.; Dubois, C.; Paulissen, C.; Kinston, S.; Göttgens, B.; et al. Defining the earliest step of cardiovascular lineage segregation by single-cell RNA-seq. Science 2018, 4174, 1-9. [CrossRef] [PubMed]

27. Ibarra-Soria, X.; Jawaid, W.; Pijuan-Sala, B.; Ladopoulos, V.; Scialdone, A.; Jörg, D.J.; Tyser, R.C.; Calero-Nieto, F.J.; Mulas, C.; Nichols, J.; et al. Defining murine organogenesis at single-cell resolution reveals a role for the leukotriene pathway in regulating blood progenitor formation. Nat. Cell Biol. 2018, 20, 127-134. [CrossRef] 
28. Pijuan-Sala, B.; Griffiths, J.A.; Guibentif, C.; Hiscock, T.W.; Jawaid, W.; Calero-Nieto, F.J.; Mulas, C.; Ibarra-Soria, X.; Tyser, R.C.; Ho, D.L.L.; et al. A single-cell molecular map of mouse gastrulation and early organogenesis. Nature 2019, 566, 490-495. [CrossRef]

29. de Soysa, T.Y.; Ranade, S.S.; Okawa, S.; Ravichandran, S.; Huang, Y.; Salunga, H.T.; Schricker, A.; del Sol, A.; Gifford, C.A.; Srivastava, D. Single-cell analysis of cardiogenesis reveals basis for organ-level developmental defects. Nature 2019, 572, 120-124. [CrossRef]

30. Cheng, S.; Pei, Y.; He, L.; Peng, G.; Reinius, B.; Tam, P.P.; Jing, N.; Deng, Q. Single-Cell RNA-Seq Reveals Cellular Heterogeneity of Pluripotency Transition and X Chromosome Dynamics during Early Mouse Development. Cell Rep. 2019, 26, $2593-2607$. [CrossRef]

31. Xiong, H.; Luo, Y.; Yue, Y.; Zhang, J.; Ai, S.; Li, X.; Wang, X.; Zhang, Y.L.; Wei, Y.; Li, H.H.; et al. Single-Cell Transcriptomics Reveals Chemotaxis-Mediated Intraorgan Crosstalk during Cardiogenesis. Circ. Res. 2019, 125, 398-410. [CrossRef]

32. Jia, G.; Preussner, J.; Chen, X.; Guenther, S.; Yuan, X.; Yekelchyk, M.; Kuenne, C.; Looso, M.; Zhou, Y.; Teichmann, S.; et al. Single cell RNA-seq and ATAC-seq analysis of cardiac progenitor cell transition states and lineage settlement. Nat. Commun. 2018, 9 , 1-17. [CrossRef]

33. Mittnenzweig, M.; Mayshar, Y.; Cheng, S.; Ben-Yair, R.; Hadas, R.; Rais, Y.; Chomsky, E.; Reines, N.; Uzonyi, A.; Lumerman, L.; et al. A single-embryo, single-cell time-resolved model for mouse gastrulation. Cell 2021, 184, 2825-2842. [CrossRef]

34. Chen, Q.; Shi, J.; Tao, Y.; Zernicka-Goetz, M. Tracing the origin of heterogeneity and symmetry breaking in the early mammalian embryo. Nat. Commun. 2018, 9, 1-11. [CrossRef]

35. Preissl, S.; Fang, R.; Huang, H.; Zhao, Y.; Raviram, R.; Gorkin, D.U.; Zhang, Y.; Sos, B.C.; Afzal, V.; Dickel, D.E.; et al. Singlenucleus analysis of accessible chromatin in developing mouse forebrain reveals cell-type-specific transcriptional regulation. Nat. Neurosci. 2018, 21, 432-439. [CrossRef]

36. Clark, S.J.; Argelaguet, R.; Kapourani, C.A.; Stubbs, T.M.; Lee, H.J.; Alda-Catalinas, C.; Krueger, F.; Sanguinetti, G.; Kelsey, G.; Marioni, J.C.; et al. ScNMT-seq enables joint profiling of chromatin accessibility DNA methylation and transcription in single cells. Nat. Commun. 2018, 9, 1-9. [CrossRef]

37. Argelaguet, R.; Clark, S.J.; Mohammed, H.; Stapel, L.C.; Krueger, C.; Kapourani, C.A.; Imaz-Rosshandler, I.; Lohoff, T.; Xiang, Y.; Hanna, C.W.; et al. Multi-omics profiling of mouse gastrulation at single-cell resolution. Nature 2019, 576, 487-491. [CrossRef]

38. McDole, K.; Guignard, L.; Amat, F.; Berger, A.; Malandain, G.; Royer, L.A.; Turaga, S.C.; Branson, K.; Keller, P.J. In Toto Imaging and Reconstruction of Post-Implantation Mouse Development at the Single-Cell Level. Cell 2018, 175, 859-876. [CrossRef]

39. Saykali, B.; Mathiah, N.; Nahaboo, W.; Racu, M.L.; Hammou, L.; Defrance, M.; Migeotte, I. Distinct mesoderm migration phenotypes in extra-embryonic and embryonic regions of the early mouse embryo. eLife 2019, 8, e42434. [CrossRef]

40. Luecken, M.D.; Theis, F.J. Current best practices in single-cell RNA-seq analysis: A tutorial. Mol. Syst. Biol. 2019, 15, e8746. [CrossRef]

41. Rosenquist, G.C. Location and movements of cardiogenic cells in the chick embryo: The heart-forming portion of the primitive streak. Dev. Biol. 1970, 22, 461-475. [CrossRef]

42. Stainier, D.Y.; Weinstein, B.M.; Detrich, H.W.; Zon, L.I.; Fishman, M.C. Cloche, an early acting zebrafish gene, is required by both the endothelial and hematopoietic lineages. Development 1995, 121, 3141-3150. [CrossRef]

43. Gassmann, M.; Casagranda, F.; Orloli, D.; Simon, H.; Lai, C.; Kleint, R.; Lemke, G. Aberrant neural and cardiac development in mice lacking the ErbB4 neuregulin receptor. Nature 1995, 378, 390-394. [CrossRef]

44. Peshkovsky, C.; Totong, R.; Yelon, D. Dependence of cardiac trabeculation on neuregulin signaling and blood flow in zebrafish. Dev. Dyn. 2011, 240, 446-456. [CrossRef]

45. Nakajima, Y.; Mironov, V.; Yamagishi, T.; Nakamura, H.; Markwald, R.R. Expression of smooth muscle alpha-actin in mesenchymal cells during formation of avian endocardial cushion tissue: A role for transforming growth factor $\beta 3$. Dev. Dyn. 1997, 209, 296-309. [CrossRef]

46. Brown, C.B.; Boyer, A.S.; Runyan, R.B.; Barnett, J.V. Antibodies to the type II TGF $\beta$ receptor block cell activation and migration during atrioventricular cushion transformation in the heart. Dev. Biol. 1996, 174, 248-257. [CrossRef]

47. Feng, W.; Chen, L.; Nguyen, P.K.; Wu, S.M.; Li, G. Single Cell Analysis of Endothelial Cells Identified Organ-Specific Molecular Signatures and Heart-Specific Cell Populations and Molecular Features. Front. Cardiovasc. Med. 2019, 6, 165. [CrossRef]

48. Drake, C.J.; Fleming, P.A. Vasculogenesis in the day 6.5 to 9.5 mouse embryo. Blood 2000, 95, 1671-1679. [CrossRef]

49. De La Pompa, J.L.; Timmerman, L.A.; Takimoto, H.; Yoshida, H.; Elia, A.J.; Samper, E.; Potter, J.; Wakeham, A.; Marengere, L.; Langille, B.L.; et al. Role of the NF-ATc transcription factor in morphogenesis of cardiac valves and septum. Nature 1998, 392, 182-186. [CrossRef]

50. Poelmann, R.E.; Gittenberger-de Groot, A.C. Development and evolution of the metazoan heart. Dev. Dyn. 2019, 248, 634-656. [CrossRef]

51. Muñoz-Chápuli, R.; Carmona, R.; Guadix, J.A.; Macías, D.; Pérez-Pomares, J.M. The origin of the endothelial cells: An evo-devo approach for the invertebrate/vertebrate transition of the circulatory system. Evol. Dev. 2005, 7, 351-358. [CrossRef] [PubMed]

52. Nakano, A.; Nakano, H.; Smith, K.A.; Palpant, N.J. The developmental origins and lineage contributions of endocardial endothelium. Biochim. Biophys. Acta (BBA)-Mol. Cell Res. 2016, 1863, 1937-1947. [CrossRef]

53. Conklin, E.G. Mosaic development in ascidian eggs. J. Exp. Zool. 1905, 2, 145-223. [CrossRef]

54. Petit, A.C.; Legué, E.; Nicolas, J.F. Methods in clonal analysis and applications. Reprod. Nutr. Dev. 2005, 45, 321-339. [CrossRef] 
55. Garcia-Martinez, V.; Schoenwolf, G.C. Primitive-streak origin of the cardiovascular system in avian embryos. Dev. Biol. 1993, 159, 706-719. [CrossRef]

56. Stalsberg, H.; DeHaan, R.L. The precardiac areas and formation of the tubular heart in the chick embryo. Dev. Biol. 1969, 19, 128-159. [CrossRef]

57. Mikawa, T.; Borisov, A.; Brown, A.M.; Fischman, D.A. Clonal analysis of cardiac morphogenesis in the chicken embryo using a replication-defective retrovirus: I. Formation of the ventricular myocardium. Dev. Dyn. 1992, 193, 11-23. [CrossRef]

58. Devine, W.P.; Wythe, J.D.; George, M.; Koshiba-Takeuchi, K.; Bruneau, B.G. Early patterning and specification of cardiac progenitors in gastrulating mesoderm. eLife 2014, 3, 1-23. [CrossRef] [PubMed]

59. Kattman, S.J.; Huber, T.L.; Keller, G.M. Multipotent Flk-1+ Cardiovascular Progenitor Cells Give Rise to the Cardiomyocyte, Endothelial, and Vascular Smooth Muscle Lineages. Dev. Cell 2006, 11, 723-732. [CrossRef] [PubMed]

60. Milgrom-Hoffman, M.; Harrelson, Z.; Ferrara, N.; Zelzer, E.; Evans, S.M.; Tzahor, E. The heart endocardium is derived from vascular endothelial progenitors. Development 2011, 138, 4777-4787. [CrossRef]

61. Misfeldt, A.M.; Boyle, S.C.; Tompkins, K.L.; Bautch, V.L.; Labosky, P.A.; Baldwin, H.S. Endocardial cells are a distinct endothelial lineage derived from Flk1+ multipotent cardiovascular progenitors. Dev. Biol. 2009, 333, 78-89. [CrossRef]

62. Motoike, T.; Markham, D.W.; Rossant, J.; Sato, T.N. Evidence for novel fate of Flk1+ progenitor: Contribution to muscle lineage Genesis 2003, 35, 153-159. [CrossRef]

63. Bu, L.; Jiang, X.; Martin-Puig, S.; Caron, L.; Zhu, S.; Shao, Y.; Roberts, D.J.; Huang, P.L.; Domian, I.J.; Chien, K.R. Human ISL1 heart progenitors generate diverse multipotent cardiovascular cell lineages. Nature 2009, 460, 113-117. [CrossRef]

64. Tyser, R.C.; Mahammadov, E.; Nakanoh, S.; Vallier, L.; Scialdone, A.; Srinivas, S. Single-cell transcriptomic characterization of a gastrulating human embryo. Nature 2021, 600, 285-289. [CrossRef]

65. Moretti, A.; Caron, L.; Nakano, A.; Lam, J.T.; Bernshausen, A.; Chen, Y.; Qyang, Y.; Bu, L.; Sasaki, M.; Martin-Puig, S.; et al. Multipotent Embryonic Isl1+Progenitor Cells Lead to Cardiac, Smooth Muscle, and Endothelial Cell Diversification. Cell 2006, 127, 1151-1165. [CrossRef] [PubMed]

66. Wu, S.M.; Fujiwara, Y.; Cibulsky, S.M.; Clapham, D.E.; ling Lien, C.; Schultheiss, T.M.; Orkin, S.H. Developmental Origin of a Bipotential Myocardial and Smooth Muscle Cell Precursor in the Mammalian Heart. Cell 2006, 127, 1137-1150. [CrossRef] [PubMed]

67. Stanley, E.G.; Biben, C.; Elefanty, A.; Barnett, L.; Koentgen, F.; Robb, L.; Harvey, R.P. Efficient cre-mediated deletion in cardiac progenitor cells conferred by a 3'UTR-ires-Cre allele of the homeobox gene Nkx2-5. Int. J. Dev. Biol. 2002, 46, 431-439. [CrossRef] [PubMed]

68. Bussmann, J.; Bakkers, J.; Schulte-Merker, S. Early endocardial morphogenesis requires Scl/Tal1. PLoS Genet. 2007, 3, 1425-1437. [CrossRef] [PubMed]

69. Schoenebeck, J.J.; Keegan, B.R.; Yelon, D. Vessel and Blood Specification Override Cardiac Potential in Anterior Mesoderm. Dev. Cell 2007, 13, 254-267. [CrossRef]

70. Chan, M.M.; Smith, Z.D.; Grosswendt, S.; Kretzmer, H.; Norman, T.M.; Adamson, B.; Jost, M.; Quinn, J.J.; Yang, D.; Jones, M.G.; et al. Molecular recording of mammalian embryogenesis. Nature 2019, 570, 77-82. [CrossRef] [PubMed]

71. McKenna, A.; Findlay, G.M.; Gagnon, J.A.; Horwitz, M.S.; Schier, A.F.; Shendure, J. Whole-organism lineage tracing by combinatorial and cumulative genome editing. Science 2016, 353, aaf7907. [CrossRef]

72. Elsasser, W.M. Outline of a theory of cellular heterogeneity. Proc. Natl. Acad. Sci. USA 1984, 81, 5126-5129. [CrossRef] [PubMed]

73. Cao, J.; Spielmann, M.; Qiu, X.; Huang, X.; Ibrahim, D.M.; Hill, A.J.; Zhang, F.; Mundlos, S.; Christiansen, L.; Steemers, F.J.; et al. The single-cell transcriptional landscape of mammalian organogenesis. Nature 2019, 566, 496-502. [CrossRef]

74. Haghverdi, L.; Büttner, M.; Wolf, F.A.; Buettner, F.; Theis, F.J. Diffusion pseudotime robustly reconstructs lineage branching. Nat. Methods 2016, 13, 845-848. [CrossRef] [PubMed]

75. Cusanovich, D.A.; Reddington, J.P.; Garfield, D.A.; Daza, R.M.; Aghamirzaie, D.; Marco-Ferreres, R.; Pliner, H.A.; Christiansen, L.; Qiu, X.; Steemers, F.J.; et al. The cis-regulatory dynamics of embryonic development at single-cell resolution. Nature 2018, 555, 538-542. [CrossRef]

76. Pijuan-Sala, B.; Wilson, N.K.; Xia, J.; Hou, X.; Hannah, R.L.; Kinston, S.; Calero-Nieto, F.J.; Poirion, O.; Preissl, S.; Liu, F.; et al. Single-cell chromatin accessibility maps reveal regulatory programs driving early mouse organogenesis. Nat. Cell Biol. 2020, 22, 487-497. [CrossRef]

77. Crispatzu, G.; Rehimi, R.; Pachano, T.; Bleckwehl, T.; Cruz-Molina, S.; Xiao, C.; Mahabir, E.; Bazzi, H.; Rada-Iglesias, A. The chromatin, topological and regulatory properties of pluripotency-associated poised enhancers are conserved in vivo. Nat. Commun. 2021, 12, 4344. [CrossRef]

78. Wang, A.; Yue, F.; Li, Y.; Xie, R.; Harper, T.; Patel, N.A.; Muth, K.; Palmer, J.; Qiu, Y.; Wang, J.; et al. Epigenetic priming of enhancers predicts developmental competence of hESC-derived endodermal lineage intermediates. Cell Stem Cell 2015, 16, 386-399. [CrossRef]

79. Grosswendt, S.; Kretzmer, H.; Smith, Z.D.; Kumar, A.S.; Hetzel, S.; Wittler, L.; Klages, S.; Timmermann, B.; Mukherji, S.; Meissner A. Epigenetic regulator function through mouse gastrulation. Nature 2020, 584, 102-108. [CrossRef]

80. Takeuchi, J.K.; Bruneau, B.G. Directed transdifferentiation of mouse mesoderm to heart tissue by defined factors. Nature 2009, 459, 708-711. [CrossRef] 
81. Arai, A.; Yamamoto, K.; Toyama, J. Murine cardiac progenitor cells require visceral embryonic endoderm and primitive streak for terminal differentiation. Dev. Dyn. 1997, 210, 344-353. [CrossRef]

82. Varner, V.D.; Taber, L.A. Not just inductive: A crucial mechanical role for the endoderm during heart tube assembly. Development 2012, 139, 1680-1690. [CrossRef] [PubMed]

83. Rowton, M.; Guzzetta, A.; Rydeen, A.B.; Moskowitz, I.P. Control of cardiomyocyte differentiation timing by intercellular signaling pathways. Semin. Cell Dev. Biol. 2021, 118, 94-106. [CrossRef]

84. Alsan, B.H.; Schultheiss, T.M. Regulation of avian cardiogenesis by Fgf8 signaling. Development 2002. 129, $1935-43$. [CrossRef]

85. Brown, K.; Doss, M.X.; Legros, S.; Artus, J.; Hadjantonakis, A.K.; Foley, A.C. Extraembryonic endoderm (XEN) stem cells producefactors that activate heart formation. PLoS ONE 2010, 5, e13446. [CrossRef] [PubMed]

86. Tzahor, E. Wnt/ $\beta$-Catenin Signaling and Cardiogenesis: Timing Does Matter. Dev. Cell 2007, 13, 10-13. [CrossRef] [PubMed]

87. Zhao, M.; Tang, Y.; Zhou, Y.; Zhang, J. Deciphering Role of Wnt Signalling in Cardiac Mesoderm and Cardiomyocyte Differentiation from Human iPSCs: Four-dimensional control of Wnt pathway for hiPSC-CMs differentiation. Sci. Rep. 2019, 9, 1-15. [CrossRef]

88. Lewis-Israeli, Y.R.; Wasserman, A.H.; Aguirre, A. Heart organoids and engineered heart tissues: Novel tools for modeling human cardiac biology and disease. Biomolecules 2021, 11, 1277. [CrossRef] [PubMed]

89. Reichman, D.E.; Park, L.; Man, L.; Redmond, D.; Chao, K.; Harvey, R.P.; Taketo, M.M.; Rosenwaks, Z.; James, D. Wnt inhibition promotes vascular specification of embryonic cardiac progenitors. Development 2018, 145, dev159905. [CrossRef] [PubMed]

90. Anderson, C.; Khan, M.A.; Wong, F.; Solovieva, T.; Oliveira, N.M.; Baldock, R.A.; Tickle, C.; Burt, D.W.; Stern, C.D. A strategy to discover new organizers identifies a putative heart organizer. Nat. Commun. 2016, 7, 1-9. [CrossRef]

91. Nemir, M.; Croquelois, A.; Pedrazzini, T.; Radtke, F. Induction of cardiogenesis in embryonic stem cells via downregulation of Notch1 signaling. Circ. Res. 2006, 98, 1471-1478. [CrossRef] [PubMed]

92. Schroeder, T.; Meier-Stiegen, F.; Schwanbeck, R.; Eilken, H.; Nishikawa, S.; Häsler, R.; Schreiber, S.; Bornkamm, G.W.; Nishikawa, S.I.; Just, U. Activated Notch1 alters differentiation of embryonic stem cells into mesodermal cell lineages at multiple stages of development. Mech. Dev. 2006, 123, 570-579. [CrossRef]

93. Han, Z.; Bodmer, R. Myogenic cells fates are antagonized by Notch only in asymmetric lineages of the Drosophila heart, with or without cell division. Development 2003, 130, 3039-3051. [CrossRef] [PubMed]

94. Rones, M.S.; McLaughlin, K.A.; Raffin, M.; Mercola, M. Serrate and Notch specify cell fates in the heart field by suppressing cardiomyogenesis. Development 2000, 127, 3865-3876. [CrossRef]

95. Chau, M.D.; Tuft, R.; Fogarty, K.; Bao, Z.Z. Notch signaling plays a key role in cardiac cell differentiation. Mech. Dev. 2006. [CrossRef] [PubMed]

96. Watanabe, Y.; Kokubo, H.; Miyagawa-Tomita, S.; Endo, M.; Igarashi, K.; Aisaki, K.I.; Kanno, J.; Saga, Y. Activation of Notch1 signaling in cardiogenic mesoderm induces abnormal heart morphogenesis in mouse. Development 2006, 133, 1625-1634. [CrossRef]

97. Gale, N.W.; Dominguez, M.G.; Noguera, I.; Pan, L.; Hughes, V.; Valenzuela, D.M.; Murphy, A.J.; Adams, N.C.; Lin, H.C.; Holash, J.; et al. Haploinsufficiency of delta-like 4 ligand results in embryonic lethality due to major defects in arterial and vascular development. Proc. Natl. Acad. Sci. USA 2004, 101, 15949-15954. [CrossRef]

98. Marcelo, K.L.; Sills, T.M.; Coskun, S.; Vasavada, H.; Sanglikar, S.; Goldie, L.C.; Hirschi, K.K. Hemogenic endothelial cell specification requires c-Kit, notch signaling, and p27-mediated cell-cycle control. Dev. Cell 2013, 27, 504-515. [CrossRef]

99. Ferdous, A.; Caprioli, A.; Iacovino, M.; Martin, C.M.; Morris, J.; Richardson, J.A.; Latif, S.; Hammer, R.E.; Harvey, R.P.; Olson, E.N.; et al. Nkx2-5 transactivates the Ets-related protein 71 gene and specifies an endothelial/endocardial fate in the developing embryo. Proc. Natl. Acad. Sci. USA 2009, 106, 814-819. [CrossRef]

100. Reischauer, S.; Stone, O.A.; Villasenor, A.; Chi, N.; Jin, S.W.; Martin, M.; Lee, M.T.; Fukuda, N.; Marass, M.; Witty, A.; et al. Cloche is a bHLH-PAS transcription factor that drives haemato-vascular specification. Nature 2016, 535, 294-298. [CrossRef]

101. Haraguchi, S.; Kitajima, S.; Takagi, A.; Takeda, H.; Inoue, T.; Saga, Y. Transcriptional regulation of Mesp1 and Mesp2 genes: Differential usage of enhancers during development. Mech. Dev. 2001, 108, 59-69. [CrossRef]

102. Matsuo, I.; Kuratani, S.; Kimura, C.; Takeda, N.; Aizawa, S. Mouse Otx2 functions in the formation and patterning of rostral head. Genes Dev. 1995, 9, 2646-2658. [CrossRef]

103. Tellier, A.P.; Archambault, D.; Tremblay, K.D.; Mager, J. The elongation factor Elof1 is required for mammalian gastrulation. PLoS ONE 2019, 14, e0219410. [CrossRef] [PubMed]

104. Ikeda, W.; Nakanishi, H.; Miyoshi, J.; Mandai, K.; Ishizaki, H.; Tanaka, M.; Togawa, A.; Takahashi, K.; Nishioka, H.; Yoshida, H.; et al. Afadin: A key molecule essential for structural organization of cell- cell junctions of polarized epithelia during embryogenesis. J. Cell Biol. 1999, 146, 1117-1132. [CrossRef] [PubMed]

105. Sun, X.; Meyers, E.N.; Lewandoski, M.; Martin, G.R. Targeted disruption of Fgf8 causes failure of cell migration in the gastrulating mouse embryo. Genes Dev. 1999, 13, 1834-1846. [CrossRef]

106. Zhao, R.; Watt, A.J.; Battle, M.A.; Li, J.; Bondow, B.J.; Duncan, S.A. Loss of both GATA4 and GATA6 blocks cardiac myocyte differentiation and results in acardia in mice. Dev. Biol. 2008, 317, 614-619. [CrossRef]

107. Gannon, M.; Bader, D. Initiation of cardiac differentiation occurs in the absence of anterior endoderm. Development 1995, 121, 2439-2450. [CrossRef] 
108. Palencia-Desai, S.; Kohli, V.; Kang, J.; Chi, N.C.; Black, B.L.; Sumanas, S. Vascular endothelial and endocardial progenitors differentiate as cardiomyocytes in the absence of Etsrp/Etv2 function. Development 2011, 138, 4721-4732. [CrossRef]

109. Tzahor, E.; Lassar, A.B. Wnt signals from the neural tube block ectopic cardiogenesis. Genes Dev. 2001, 15, 255-260. [CrossRef]

110. Marvin, M.J.; Di Rocco, G.; Gardiner, A.; Bush, S.M.; Lassar, A.B. Inhibition of Wnt activity induces heart formation from posterior mesoderm. Genes Dev. 2001, 15, 316-327. [CrossRef]

111. Chestnut, B.; Casie Chetty, S.; Koenig, A.L.; Sumanas, S. Single-cell transcriptomic analysis identifies the conversion of zebrafish Etv2-deficient vascular progenitors into skeletal muscle. Nat. Commun. 2020, 11, 1-16. [PubMed]

112. Van Handel, B.; Montel-Hagen, A.; Sasidharan, R.; Nakano, H.; Ferrari, R.; Boogerd, C.J.; Schredelseker, J.; Wang, Y.; Hunter, S.; Org, T.; et al. Scl represses cardiomyogenesis in prospective hemogenic endothelium and endocardium. Cell 2012, 150, 590-605. [CrossRef]

113. Saba, R.; Kitajima, K.; Rainbow, L.; Engert, S.; Uemura, M.; Ishida, H.; Kokkinopoulos, I.; Shintani, Y.; Miyagawa, S.; Kanai, Y.; et al. Endocardium differentiation through Sox17 expression in endocardium precursor cells regulates heart development in mice. Sci. Rep. 2019, 9, 1-11. [CrossRef]

114. Kouskoff, V.; Lacaud, G.; Schwantz, S.; Fehling, H.J.; Keller, G. Sequential development of hematopoietic and cardiac mesoderm during embryonic stem cell differentiation. Proc. Natl. Acad. Sci. USA 2005, 102, 13170-13175. [CrossRef] [PubMed]

115. Nostro, M.C.; Cheng, X.; Keller, G.M.; Gadue, P. Wnt, Activin, and BMP Signaling Regulate Distinct Stages in the Developmental Pathway from Embryonic Stem Cells to Blood. Cell Stem Cell 2008, 2, 60-71. [CrossRef] [PubMed]

116. Yang, L.; Soonpaa, M.H.; Adler, E.D.; Roepke, T.K.; Kattman, S.J.; Kennedy, M.; Henckaerts, E.; Bonham, K.; Abbott, G.W.; Linden, R.M.; et al. Human cardiovascular progenitor cells develop from a KDR+ embryonic-stem-cell-derived population. Nature 2008, 453, 524-528. [CrossRef]

117. Santini, M.P.; Forte, E.; Harvey, R.P.; Kovacic, J.C. Developmental origin and lineage plasticity of endogenous cardiac stem cells. Development 2016, 143, 1242-1258. [CrossRef] [PubMed]

118. Van Vliet, P.; Wu, S.M.; Zaffran, S.; Pucéat, M. Early cardiac development: A view from stem cells to embryos. Cardiovasc. Res. 2012, 96, 352-362. [CrossRef]

119. Rosenquist, G.C.; DeHaan, R.L. Contributions to Embryology; Carnegie Institution of Washington: Washington, DC, USA, 1966; Volume 38, pp. 111-121.

120. Cui, C.; Cheuvront, T.J.; Lansford, R.D.; Moreno-Rodriguez, R.A.; Schultheiss, T.M.; Rongish, B.J. Dynamic positional fate map of the primary heart-forming region. Dev. Biol. 2009, 332, 212-222. [CrossRef]

121. Lopez-Sanchez, C.; Garcia-Masa, N.; Gañan, C.M.; Garcia-Martinez, V. Movement and commitment of primitive streak precardiac cells during cardiogenesis. Int. J. Dev. Biol. 2009, 53, 1445-1455. [CrossRef]

122. Redkar, A.; Montgomery, M.; Litvin, J. Fate map of early avian cardiac progenitor cells. Development 2001, 128, 2269-2279. [CrossRef] [PubMed]

123. Satin, J.; Fujii, S.; DeHaan, R.L. Development of cardiac beat rate in early chick embryos is regulated by regional cues. Dev. Biol. 1988, 129, 103-113. [CrossRef]

124. pin Wu, S.; Cheng, C.M.; Lanz, R.B.; Wang, T.; Respress, J.L.; Ather, S.; Chen, W.; Tsai, S.J.; Wehrens, X.H.; Tsai, M.J.; et al. Atrial Identity Is Determined by a COUP-TFII Regulatory Network. Dev. Cell 2013, 25, 417-426. [CrossRef]

125. Joubin, K.; Stern, C.D. Molecular interactions continuously define the organizer during the cell movements of gastrulation. Cell 1999, 98, 559-571. [CrossRef]

126. Saito, Y.; Kojima, T.; Takahashi, N. Mab2112 is essential for embryonic heart and liver development. PLoS ONE 2012,7 , e32991. [CrossRef] [PubMed]

127. Baldessari, D.; Badaloni, A.; Longhi, R.; Zappavigna, V.; Consalez, G.G. MAB21L2, a vertebrate member of the Male-abnormal 21 family, modulates BMP signaling and interacts with SMAD1. BMC Cell Biol. 2004, 5, 48. [CrossRef]

128. Domínguez, J.N.; Meilhac, S.M.; Bland, Y.S.; Buckingham, M.E.; Brown, N.A. Asymmetric fate of the posterior part of the second heart field results in unexpected left/right contributions to both poles of the heart. Circ. Res. 2012, 111, 1323-1335. [CrossRef]

129. Zaffran, S.; Kelly, R.G.; Meilhac, S.M.; Buckingham, M.E.; Brown, N.A. Right ventricular myocardium derives from the anterior heart field. Circ. Res. 2004, 95, 261-268. [CrossRef] [PubMed]

130. Mommersteeg, M.T.; Domínguez, J.N.; Wiese, C.; Norden, J.; De Gier-De Vries, C.; Burch, J.B.; Kispert, A.; Brown, N.A.; Moorman, A.F.; Christoffels, V.M. The sinus venosus progenitors separate and diversify from the first and second heart fields early in development. Cardiovasc. Res. 2010, 87, 92-101. [CrossRef]

131. Bruneau, B.G.; Nemer, G.; Schmitt, J.P.; Charron, F.; Robitaille, L.; Caron, S.; Conner, D.A.; Gessler, M.; Nemer, M.; Seidman, C.E.; et al. A murine model of Holt-Oram syndrome defines roles of the T-Box transcription factor Tbx 5 in cardiogenesis and disease. Cell 2001, 106, 709-721. [CrossRef]

132. Waddington, C.H. The Strategy of the Genes. A Discussion of Some Aspects of Theoretical Biology. With an Appendix by H. Kacser; CAB Direct: London, UK, 1957; pp 152-169.

133. Sáez, M.; Blassberg, R.; Camacho-Aguilar, E.; Siggia, E.D.; Rand, D.A.; Briscoe, J. Statistically derived geometrical landscapes capture principles of decision-making dynamics during cell fate transitions. Cell Syst. 2021, (In Press, Corrected Proof). [CrossRef]

134. Gilbert, S.F. Developmental Biology, 8th ed.; Sinauer Associates: Sunderland, MA, USA, 2006; p. 751. 
135. Guignard, L.; Fiúza, U.M.; Leggio, B.; Laussu, J.; Faure, E.; Michelin, G.; Biasuz, K.; Hufnagel, L.; Malandain, G.; Godin, C.; et al. Contact area-dependent cell communication and the morphological invariance of ascidian embryogenesis. Science 2020, 369, eaar5663. [CrossRef]

136. Wiegner, O.; Schierenberg, E. Regulative development in a nematode embryo: A hierarchy of cell fate transformations. Dev. Biol. 1999. [CrossRef] [PubMed]

137. Rossant, J. Stem Cells and Early Lineage Development. Cell 2008, 132, 527-531. [CrossRef] [PubMed]

138. Moorman, A.F.; Christoffels, V.M.; Anderson, R.H.; Van Den Hoff, M.J. The heart-forming fields: One or multiple? Philos. Trans. R. Soc. Biol. Sci. 2007, 362, 1257-1265. [CrossRef] [PubMed]

139. Cai, C.L.; Liang, X.; Shi, Y.; Chu, P.H.; Pfaff, S.L.; Chen, J.; Evans, S. Isl1 identifies a cardiac progenitor population that proliferates prior to differentiation and contributes a majority of cells to the heart. Dev. Cell 2003, 5, 877-889. [CrossRef]

140. Noden, D.M.; Poelmann, R.E.; Gittenberger-de Groot, A.C. Cell origins and tissue boundaries during outflow tract development. Trends Cardiovasc. Med. 1995, 5, 69-75. [CrossRef] 